\title{
Urbanization and Long-Term Forest Dynamics in a Metropolitan Region of Southern Europe (1936-2018)
}

\author{
Leonardo Bianchini $^{1}{ }^{(D}$, Alvaro Marucci $^{1}$, Adele Sateriano ${ }^{2, *}$, Valerio Di Stefano ${ }^{1}$, Riccardo Alemanno ${ }^{1}$ \\ and Andrea Colantoni ${ }^{1, *(D)}$ \\ 1 Department of Agriculture and Forest Sciences (DAFNE), University of Tuscia, Via S. Camillo de Lellis, \\ I-01100 Viterbo, Italy; 1.bianchini@unitus.it (L.B.); alvaro.marucci@unitus.it (A.M.); \\ valerio.distefano@unitus.it (V.D.S.); riccardo.alemanno@unitus.it (R.A.) \\ 2 Independent Researcher, Piazza S. Giovanni in Laterano, I-00185 Rome, Italy \\ * Correspondence: adele.sateriano.pul@gmail.com (A.S.); colantoni@unitus.it (A.C.)
}

check for updates

Citation: Bianchini, L.; Marucci, A.; Sateriano, A.; Di Stefano, V.;

Alemanno, R.; Colantoni, A.

Urbanization and Long-Term Forest Dynamics in a Metropolitan Region of Southern Europe (1936-2018). Sustainability 2021, 13, 12164. https:/ / doi.org/10.3390/su132112164

Academic Editors: Andrew Kirby and Marc A. Rosen

Received: 14 September 2021

Accepted: 1 November 2021

Published: 4 November 2021

Publisher's Note: MDPI stays neutral with regard to jurisdictional claims in published maps and institutional affiliations.

Copyright: (C) 2021 by the authors. Licensee MDPI, Basel, Switzerland. This article is an open access article distributed under the terms and conditions of the Creative Commons Attribution (CC BY) license (https:// creativecommons.org/licenses/by/ $4.0 /)$.
Abstract: Although peri-urban landscapes in Southern Europe still preserve a relatively high level of biodiversity in relict natural places, urban expansion is progressively consuming agricultural land and, in some cases, forest cover. This phenomenon has (direct and indirect) environmental implications, both positive and negative. The present study contributes to clarifying the intrinsic nexus between long-term urban expansion and forest dynamics in a representative Mediterranean city based on diachronic land-use maps. We discuss some counterintuitive results of urbanization as far as forest expansion, wildfire risk, and biodiversity conservation are concerned. Forest dynamics were investigated at two time intervals (1936-1974 and 1974-2018) representing distinctive socioeconomic contexts in the Rome metropolitan area in Central Italy. Additionally, the spatial relationship between forest cover and urban growth was evaluated using settlement density as a target variable. All over the study area, forest cover grew moderately over time (from $18.3 \%$ to $19.9 \%$ in the total landscape), and decreased along the urban gradient (i.e., with settlement density) more rapidly in 2018 than in 1936. The diversification of forest types (Shannon H index) was higher in areas with medium-density settlements, indicating a tendency towards more heterogeneous and mixed structures in rural and peri-urban woods that undergo rising human pressure. The dominance of a given forest type (Simpson's D index) was higher at high settlement density areas. Evenness (Pielou's J index) was the highest at low settlement density areas. The long-term assessment of land-use dynamics in metropolitan fringes enriched with a spatially explicit analysis of forest types may inform regional planning and environmental conservation, which could delineate appropriate strategies for sustainable land management in Southern European cities.

Keywords: land-use changes; diachronic maps; socioeconomic contexts; Southern Europe

\section{Introduction}

Land-use change has been demonstrated to cause, in many cases, physical fragmentation, ecological simplification and the biological deterioration of natural ecosystems [1-3]. At the same time, ecosystem degradation due to human-driven landscape change is associated with biodiversity loss [4-6]. Landscape fragmentation was hardly quantifiable over larger time scales, and was more appropriate as a reflection of the synergic effect of climate change and human pressure on both agricultural systems and marginal, natural land [7-9]. These modifications resulted in landscape homogenization, although some processes of change remained largely unclarified [10].

Urbanization, cropland decline, and the natural reforestation of pastures made the wildland-urban interface extremely diversified and heterogeneous [11-13]. Fueled by population increases and economic growth [14], settlement expansion has altered fringe landscapes for a long time $[2,15,16]$. Fringe land results in the physical overlap of settlements and natural habitats including forests $[17,18]$. These landscapes represent a complex 
ecosystem and a sort of laboratory for integrated monitoring and planning that experiences threats such as wildfires, sealing, pollution, and increases in invasive species [19]. Assessing the transformations of fringe landscapes means understanding the intimate interplay of urbanization, agricultural intensification and land abandonment. Understanding this knowledge is a basis for sustainable land management $[20,21]$.

Metropolitan landscapes in Europe experienced rapid and intense transformations during the last century following urbanization, economic growth, and infrastructural development [12,22-24]. A considerable decline in agricultural land together with a parallel expansion of settlements and forests was observed in Mediterranean Europe, a recognized hotspot of landscape change, reflecting the shift from rural to urban lifestyles [25-27]. Featuring a persistent interplay between nature and humans [28-30], fringe landscapes in Southern Europe have been especially affected by rapid urbanization, which has determined the progressive abandonment of the surrounding uplands and mountains, resulting in their natural forestation [31-33]. At the same time, coastal areas were transformed into anthropogenic and fragmented land mosaics [34-37].

In Italy, fringe landscapes expanded largely following metropolitan growth [33]. Fringe landscape changes included (i) the abandonment of marginal land causing a parallel increase in forest cover, (ii) intensified agricultural systems on flat land, and (iii) urban expansion with economic decentralization towards suburban locations. Rome is one of the best examples of metropolitan development and fringe transformation in Italy (16). The evolution of the socioeconomic context fueled legal and informal settlement expansion that generated a complex mosaic of fringe landscapes [38]. In these regards, the traditional (rural and socially permeable) landscape surrounding Rome provided the necessary source of buildable land for such a transformation $[10,16,39,40]$, while undergoing a progressive homogenization and simplification during the last century [20]. Despite a generalized decrease in natural and semi-natural areas [41] and the loss of a primary cultural heritage [42] because of urban expansion, fringe landscapes in Rome still preserve biodiversity within a mosaic of croplands, relict forests, pastures, and shrublands [42], thanks to nearly 40 protected areas and more than 50 Natura 2000 sites covering about $20 \%$ of Rome's metropolitan area [36].

Taken together, this context represents a paradigmatic case reflecting long-term urbanforest dynamics at the fringe and justifies a specific investigation of land-use changes and settlement growth covering more than 80 years, a time window encompassing the whole development cycle of forests. We assumed a non-linear effect of urban expansion on natural landscapes, such as threatening agricultural systems and consuming fertile soils around settlements. At the same time, we assume forests, generally concentrated in economically marginal locations of metropolitan regions, indirectly benefit from urban expansion, thanks to the reforestation of (progressively abandoned) cultivated land. Two time intervals (1936-1974 and 1974-2018) corresponding to distinctive socioeconomic contexts at the local level were considered when assessing long-term changes in forest cover and the spatial relationship with settlement expansion in the study area. The present work illustrates a joint analysis of fringe forest dynamics based on a specific assessment of selected forest types. The final aim of this study is to inform appropriate strategies of sustainable development, regional planning, and land management in light of an integrated governance of fringe land in contemporary cities.

\section{Materials and Methods}

\subsection{Study Area}

We studied a metropolitan area encompassing Rome's prefecture $\left(5355 \mathrm{~km}^{2}\right)$ that corresponds to the NUTS-3 level of the European nomenclature of territorial statistics; this area has $30 \%$ flat land and $20 \%$ highly steep land that is up to $1820 \mathrm{~m}$ above sea level in the Apennine district [38]. The area was administered by 122 municipalities, the largest being Rome $\left(1285 \mathrm{~km}^{2}\right)$. The lowlands are concentrated in the alluvial plain of the Tiber 
River. A brief description of the area is provided in Table 1, which considers territorial and demographic indicators together.

Table 1. Demographic and territorial characteristics of Rome's metropolitan area at selected years based on official statistics.

\begin{tabular}{cccc}
\hline Indicator & $\mathbf{1 9 3 6}$ & $\mathbf{1 9 7 1}$ & $\mathbf{2 0 2 0}$ \\
\hline Land surface $\left(\mathrm{km}^{2}\right)$ & & 5354 & \\
Resident population & $2,775,380$ & $3,761,067$ & $4,227,588$ \\
Population density (inhabitants km ${ }^{-2}$ ) & 518 & 702 & 790 \\
Population growth (\% by year) & 2.8 & 0.5 & 0.2 \\
Suburban/urban population (\%) & 26.9 & 35.5 & 47.9 \\
Urban population density (inhabitants km ${ }^{-2}$ ) & 1460 & 1852 & 1860 \\
Urban population annual growth (\%) & 3.2 & -0.1 & -0.2 \\
Suburban population density (inhab. $\mathrm{km}^{-2}$ ) & 152 & 256 & 362 \\
Suburban population annual growth $(\%)$ & 1.8 & 1.5 & 1.4 \\
\hline
\end{tabular}

Industrial and service settlements were located east of Rome, whereas a mosaic of cropland and forests were located west of the city [16]. As a result of occasional degradation due to wildfires and rising human pressures, a sparse forest cover was preserved in both coastal and upland districts [20]. Road infrastructure was diffused all over the study area. Areas located at a distance of more than $1 \mathrm{~km}$ from national roads are relatively scarce and concentrated only in remote districts (Figure 1). The climate in the area is typically Mediterranean, with rainfalls concentrated in autumn and spring and mild temperature in winter. The average long-term (1981-2010) annual precipitation and mean air temperature were $700 \mathrm{~mm}$ and $17^{\circ} \mathrm{C}$, respectively [43].

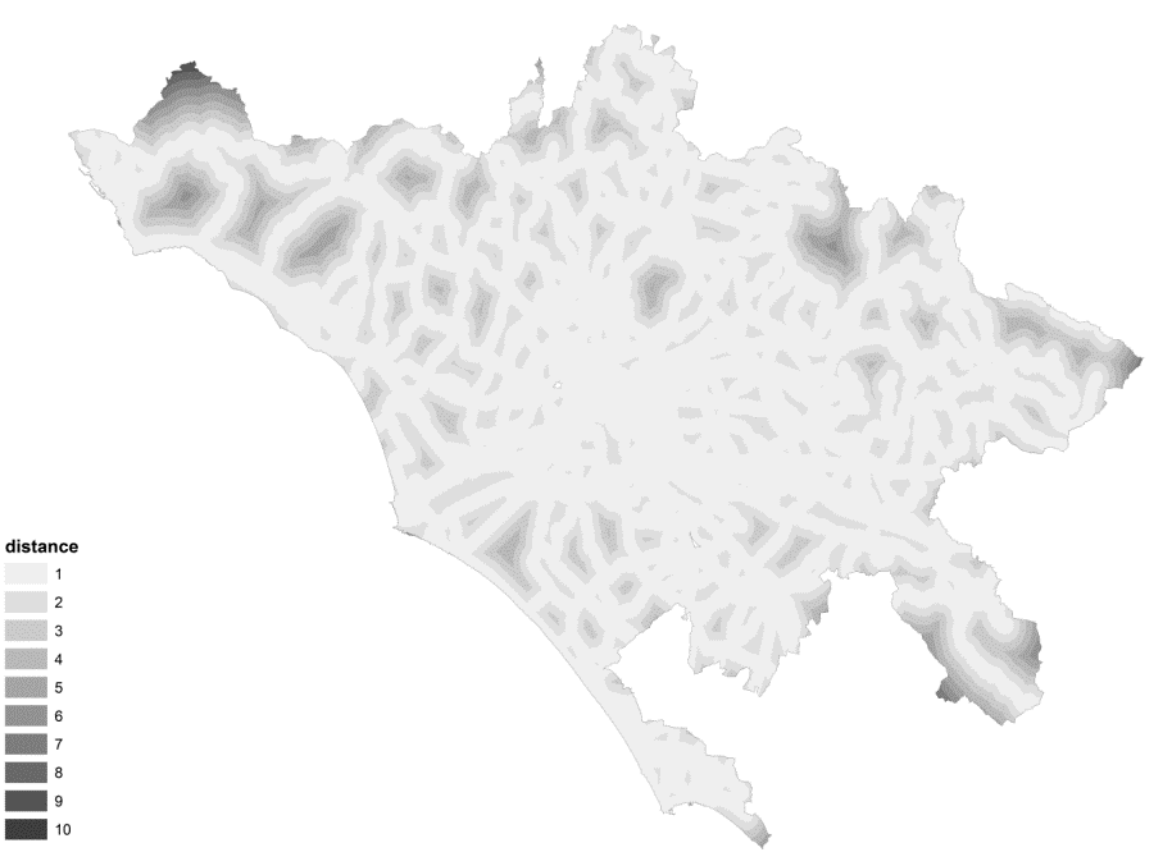

Figure 1. Land classification based on the linear distance $(\mathrm{km})$ from road infrastructure.

\subsection{Settlement Maps}

Diachronic maps of building density (produced by aerial photograph processing at $1: 10,000$ scale in urban areas and 1:25,000 scale in rural areas, including the axis of the streets and the outlines of the blocks) were derived from the geographical information system supporting the National Censuses of Population and Households in Italy. The density of buildings was calculated in 1945, 1971, and 2011 from data collected in the framework of the national census of buildings by the Italian National Institute of Statistics 
(Istat). In the above-mentioned years, maps were derived from the digital data available at the census tract scale. The vector map obtained from Istat reports the geometry of nearly 16,000 enumeration districts corresponding to 5-10 building blocks in urban areas and 20-50 blocks in rural areas, depending on population density and land constraints (elevation, rivers, lakes, and the sea coast). The surface area of each enumeration district was calculated using ArcGIS "spatial analyst" tools (Esri Inc., Redwoods, CA, USA). The building density was calculated at each enumeration district polygon for each study year. To estimate the spatial distribution of settlements, enumeration districts were classified into four density classes: (i) $<0.5$ buildings per hectare, (ii) $0.6-5.0$ buildings per hectare, (iii) 5.1-10 buildings per hectare, and (iv) $>10$ buildings per hectare. The total surface area of each density class was calculated by summing up the surface area of each enumeration district within that class.

\subsection{Forest Maps}

We considered three thematic land cover maps of Rome's metropolitan area, spanning between 1936 and 2018 and with a similar resolution (1:100,000 nominal scale): (i) the forest map produced by the Italian Milizia Forestale (the Italian Forest Service during the fascist epoque) as part of the first national forest inventory dated to 1936 and digitized according to three independent layers (sea coast, administrative boundaries, and roads); (ii) the 'agro-forest map' of Rome province that is dated to 1974 and that was recently made available in a digital format (shapefiles) by the Cartographic Service of the Rome metropolitan area; and (iii) the Corine land cover map of Italy dated to 2018 and provided by the Italian National Institute for Environmental Protection and Research (ISPRA) at the fourth level of the European NUTS classification. Four types of forest management were considered the most common information in all maps (chestnut, beech, conifer, and mixed broadleaf). To verify the precision of the aggregate information derived from the three maps, we considered additional datasets from independent sources providing estimates of forest cover, including: (i) the annual forest surveys (Istat), (ii) a 1:25,000 topographic map produced by the Italian Military Geographic Institute (Florence) dated to 1949, (iii) national forest inventories dated to 1985 and 2003, (iv) land-use maps produced by the National Research Council, the Italian Cadastre, and the Italian Touring Club referring to the early 1960s, (v) four Corine land cover maps dated to 1990, 2000, 2006 and 2012 and, finally, (vi) the 1:25,000 'land-use map of Latium region' produced in 1999 and updated in 2016 by the Cartographic Service of the Regional Authority of Latium.

\subsection{Statistical Analysis}

Two sources of data (population censuses and forest maps) with a slightly different timetable were adopted in this study. We assume this is acceptable when the chronological difference between observations is low enough, as in this case, and when the investigated period is sufficiently long and justifies some minor disalignments in the survey timetable, such as in a historical context (for instance, World War II). The latter case was deemed acceptable when the availability of geospatial, digital data was structurally restricted [44]. In order to reduce the eventual effect of this disalignment on the empirical results, we calculated indicators on an annual basis (e.g., percent rates of change as the average annual value for each time period investigated) when appropriate. The three forest maps were separately overlaid with the respective building maps illustrated above (1936 forest maps vs. 1945 building map, 1974 forest map vs. 1971 building map, 2018 forest map vs. 2011 building map). The shapefile intersect of 'forest' polygons with 'settlement' polygons was created using the ArcGIS (Esri Inc., Redwoods, CA, USA) 'intersect' tool. Settlement density was calculated at each study year; forest cover was estimated at each density class by wood type.

To assess changes over time in the spatial distribution of wood types along the fringe, three well-known landscape indexes were calculated by year and settlement density: 
(i) Simpson's dominance index (D) evaluating the proportion of the most abundant wood type in the landscape, (ii) the Shannon $\mathrm{H}$ diversity index (ranging between 0 and infinity, with increasing values that indicate a high landscape diversification) and (iii) Pielou's J evenness index, both of which consider the proportion of wood types in each settlement density class. Pielou's J index was estimated as the ratio of the Shannon H index to the maximum potential $\mathrm{H}$ value based on the number $(\mathrm{W})$ of wood types $\left(\mathrm{H}_{\max }=\ln (\mathrm{W})\right)$ recorded at each density class. Pielou's index ranges between 0 (low evenness) and 1 (high evenness), indicating a balanced forest composition with increasing J values. $\mathrm{D}, \mathrm{H}$, and $\mathrm{J}$ values were finally plotted against settlement density separately for the beginning (1936) and the end (2018) of the study year.

\section{Results}

\subsection{Changes in Forest Cover over Time, 1936-2018}

Forests expanded during the study period from $18.3 \%$ to $19.9 \%$ of the total landscape (Table 2). The total area of chestnut, beech, and conifer stands decreased moderately over the first time interval (1936-1974), although they increased afterwards.

Table 2. Change over time in forest cover, Rome's metropolitan area (1936-2018).

\begin{tabular}{cccccc}
\hline \multirow{2}{*}{ Year } & \multirow{2}{*}{$\begin{array}{c}\text { Forests in Total } \\
\text { Landscape (\%) }\end{array}$} & \multicolumn{3}{c}{ Forest Type Area (\% in Total Forest Stock) } \\
\cline { 3 - 5 } & 18.3 & 13.8 & 10.1 & 1.7 & 74.4 \\
& 19.7 & 10.2 & 8.5 & 1.7 & 79.6 \\
1936 & 19.9 & 18.5 & 9.8 & 3.0 & 68.7 \\
\hline
\end{tabular}

Chestnuts and conifers increased, respectively, from $13.8 \%$ to $18.5 \%$ and from $1.7 \%$ to $3.0 \%$ of the total forest stock. In turn, beech experienced a moderate decline from $10.1 \%$ to $9.8 \%$ of the total forest stock. The long-term evolution of forest cover (Figure 2) suggests that multiple socioeconomic forces have stimulated landscape transformations along the urban gradient in Rome. Cropland abandonment around Rome was a factor fueling, at least indirectly, natural afforestation upland. At the same time, urbanization determined a progressive fragmentation of relict forests around the city.
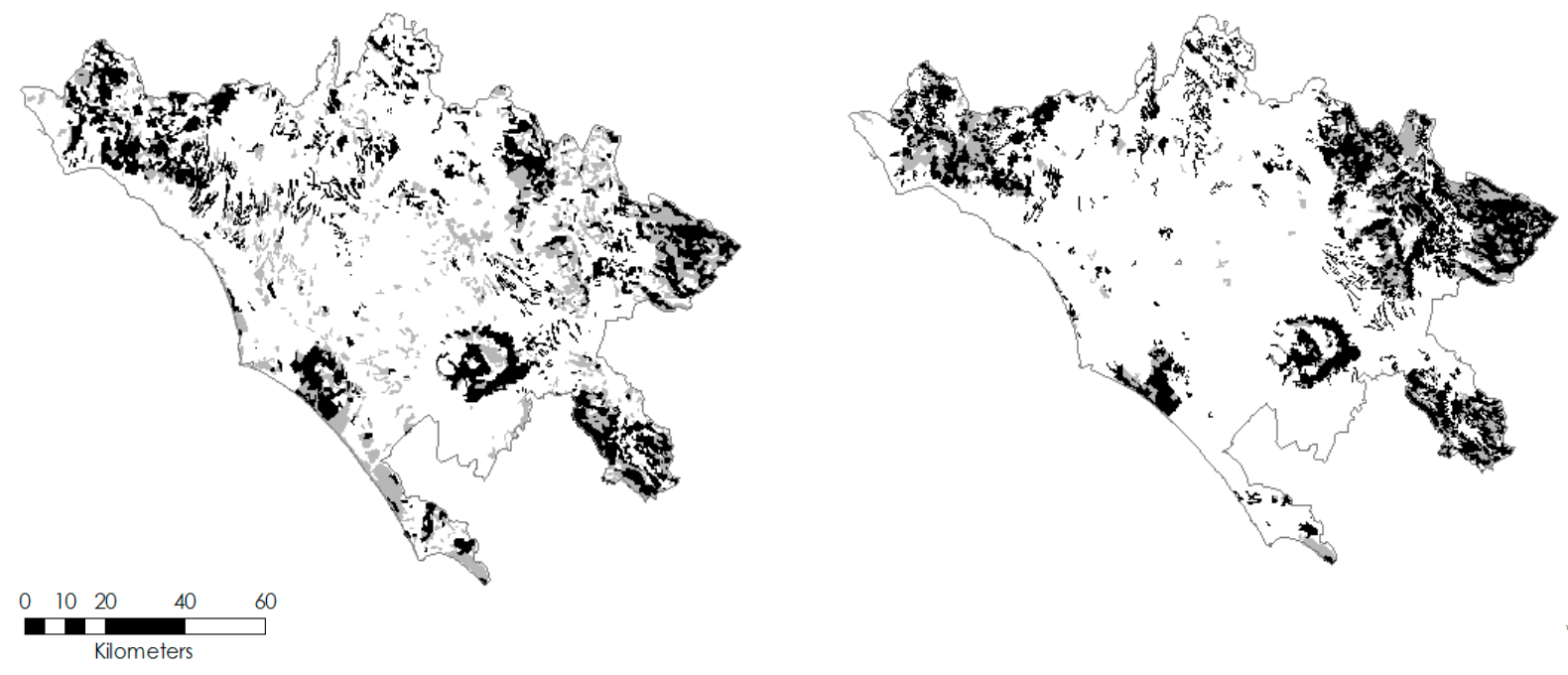

Figure 2. The spatial distribution of forest cover in Rome's metropolitan area, 1936 (left) and 2018 (right). 
A specific analysis of forest cover (percent of total landscape) by distance from downtown Rome indicates a substantial increase in woodland area moving further away from the inner cities (Figure 3), reaching the highest value (50\% of the total landscape) at distances of $>30 \mathrm{~km}$.

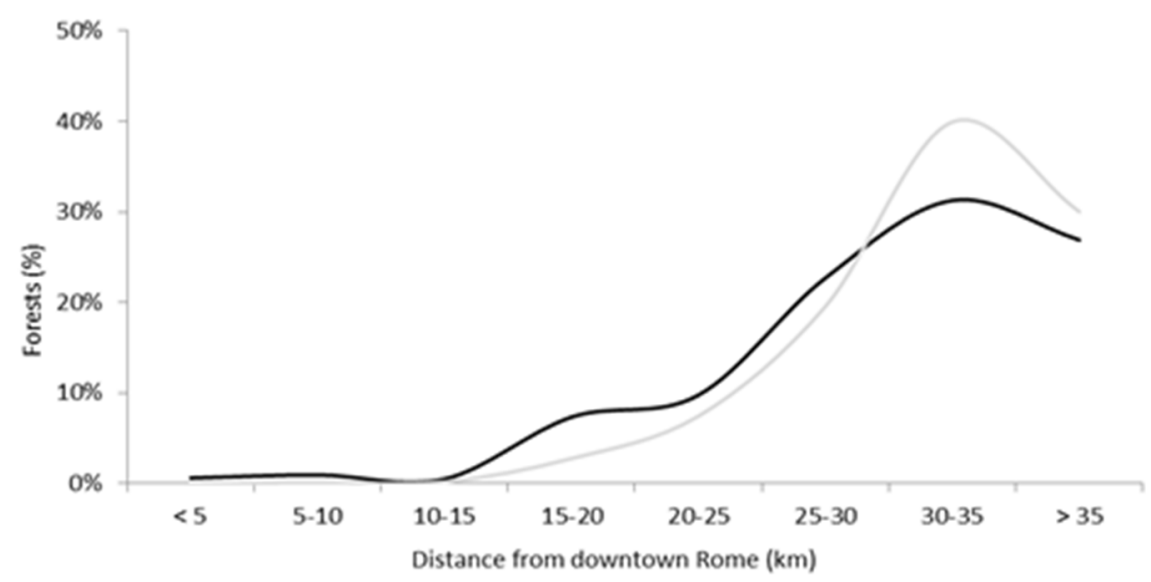

Figure 3. The spatial distribution of forest cover (\%) and distance from downtown Rome at the beginning (1936, black line) and the end (2018, grey line) of the study period in Rome.

Comparing the same distance profile at the beginning (1936) and the end (2018) of the study period, an evident concentration of forest land in remote areas was observed thanks to land abandonment and natural/human-driven forestation. A parallel, slighter expansion along the fringe (distance of $<10 \mathrm{~km}$ from downtown Rome) was also observed, suggesting that peri-urbanization went hand in hand with forest preservation and cropland decline. Another net effect of land-use changes over the last 80 years in Rome was the generalized reduction in forest cover at intermediate distances from the city, corresponding to largely accessible, rural districts that originally preserved a diversified landscape matrix that mixed cropland, pastures, forests and shrublands. This was progressively simplified into more intensive agricultural systems.

\subsection{Urban Growth and Forest Cover in Metropolitan Rome}

Forest landscapes displayed a different evolution over time depending on settlement density (Table 3).

Table 3. Percent distribution of the total forest stock by class of settlement density (buildings/hectare) and year in Rome's metropolitan area.

\begin{tabular}{ccccc}
\hline Year & $<\mathbf{0 . 5}$ & $\mathbf{0 . 6}-\mathbf{5}$ & $\mathbf{5 . 1 - 1 0 . 0}$ & $>\mathbf{1 0}$ \\
\hline 1936 & 89.1 & 9.3 & 0.5 & 1.1 \\
1974 & 62.5 & 29.8 & 3.2 & 4.5 \\
2018 & 54.4 & 25.5 & 8.5 & 11.6 \\
\hline
\end{tabular}

Forest cover structurally decreased with settlement density, although this occurred with a distinctive trend at the beginning and the end of the study period: $89 \%$ of forest cover was concentrated in low-density rural areas ( $<0.5$ buildings per hectare) in 1936, whereas it decreased substantially in 1974 (62.5\%) and 2018 (54.4\%). Conversely, forest cover in the intermediate class of settlement density (0.5-5 buildings/hectare) increased over time from $9 \%$ (1936) to 30\% (1974) and 26\% (2018). Forest cover was relatively scarce in fringe land ( $>5$ buildings/hectare), whereas it increased substantially over time (from $2 \%$ in 1936 to nearly $20 \%$ in 2018). This trend is consistent with the findings presented above and indicates a substantial shift in the spatial distribution of woodlands becoming progressively closer to medium-density settlements. 


\subsection{Urban Growth and Wood Types in Metropolitan Rome}

A specific analysis of wood types indicates a substantial decline further away from central locations, especially in the first time interval, with a counter-intuitive, moderate increase near settlements in more recent decades (Table 4).

Table 4. Percent distribution of wood types by class of settlement density (buildings/hectare) and year in Rome's metropolitan area.

\begin{tabular}{ccccc}
\hline Year & $<\mathbf{0 . 5}$ & $\mathbf{0 . 6 - 5}$ & $\mathbf{5 . 1 - 1 0 . 0}$ & $>\mathbf{1 0}$ \\
\hline & & Chestnut & & \\
1936 & 81.5 & 14.6 & 0.5 & 3.4 \\
1974 & 64.6 & 28.1 & 0.2 & 7.1 \\
2018 & 49.0 & 28.3 & 7.3 & 15.4 \\
\hline & & Beech & & \\
1936 & 99.5 & 0.3 & 0.0 & 0.2 \\
1974 & 94.0 & 5.3 & 0.0 & 0.7 \\
2018 & 82.9 & 13.9 & 2.4 & 0.8 \\
\hline & & Conifers & & \\
1936 & 91.3 & 4.3 & 0.9 & 3.5 \\
1974 & 66.0 & 29.0 & 0.9 & 4.1 \\
2018 & 71.1 & 17.1 & 7.2 & 4.6 \\
\hline & & & \\
1936 & 89.0 & Mixed Broadleaf & 0.5 & 0.8 \\
1974 & 58.7 & 9.7 & 4.0 & 4.6 \\
2018 & 51.2 & 32.9 & 10.0 & 12.7 \\
\hline
\end{tabular}

The concentration of chestnut woods decreased at low settlement density areas (from $81.5 \%$ to $49 \%$, with a comparable decline in the two time intervals), increased at higher settlement density areas and concentrated 15\% of chestnut stands in 2018 along the fringe (settlement density $>5$ inhabitants $/ \mathrm{km}^{2}$ ). Confirming the spatial distribution of beech woods at a higher elevation in Rome, this wood type decreased moderately in the lowdensity class of settlement density from $99 \%$ (1936) to $83 \%$ (2018). However, a residual $14 \%$ of beech cover concentrated in the $0.5-5$ buildings/hectare class in 2018 . The two densest classes accounted only for $1-3 \%$ of beech stands, irrespective of the observation year. Conifers showed a more mixed trend, decreasing over time in low-density settlements and increasing in high-density settlements. Small differences between wood types did not depart from a spatial shift of forest cover from less to more dense settlements.

\subsection{Urban Growth and Wood Type Diversification}

Figure 4 shows the relationship between forest diversification in different wood types and settlement density over time. The highest dominance was observed in medium-high density settlements and reflects poorly diversified natural contexts with a given, dominant wood type. The lowest dominance index was observed in medium-low settlements, representing a landscape matrix that integrates mixed cropland, multi-species wood types, shrubland and pastures.

The highest Shannon diversity $(\mathrm{H})$ was observed in medium-low density settlements. At the same time, the highest Pielou's evenness (J) index was observed in rural landscapes with low (or very low) building density and reflects well-balanced forest communities with moderate dominance of a given wood class and substantial diversification in multiple stand/species types. 

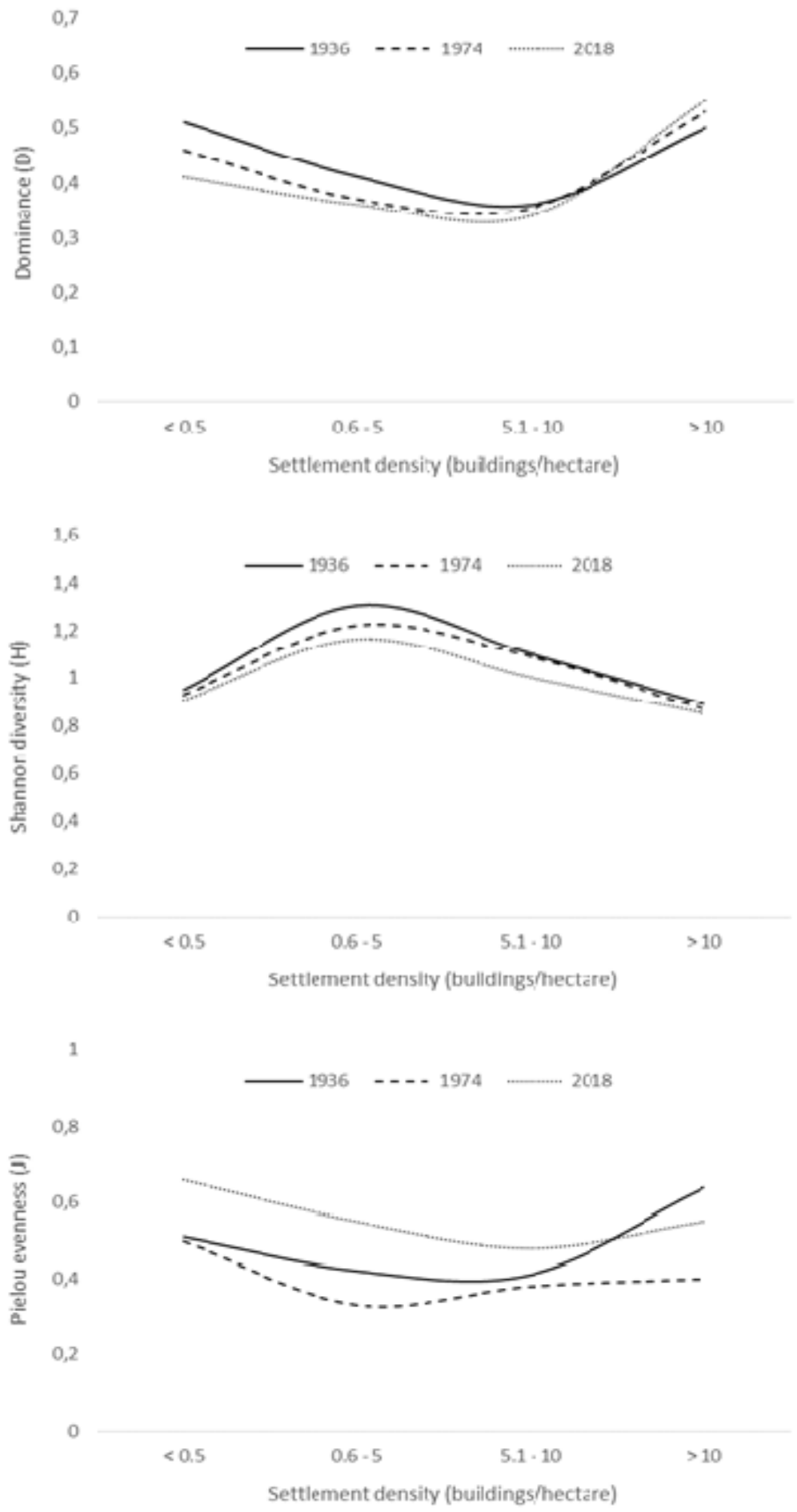

Figure 4. Spatial distribution of landscape metrics (Simpson's D dominance, Shannon H diversity, Pielou's J evenness) by settlement density class in Rome's metropolitan area.

\section{Discussion}

Economic transformations in Mediterranean Europe shaped land-use over the last century. The synergic action of multiple drivers of change clearly complicates the integrated assessment of urban growth and forest cover in fringe landscapes. Although this study documents the expansion of forests in parallel with intense urban expansion over the last 80 years in Rome, the empirical results of our study justify the need for a permanent assessment of landscape dynamics and the appropriateness of environmental measures involving the impact of urban expansion on forest cover. Natural/human-driven forestation 
and cropland abandonment in economically marginal and disadvantaged districts should be better managed [45], and clear-cutting in flat areas-which frequently occurred in the 1950s and the 1960s—should be systematically avoided [46].

A spatial explicit analysis of forest cover and settlement growth provides a basic tool for monitoring long-term landscape transformations and ecosystem quality [47]. More than $75 \%$ of forest cover in Rome was concentrated on rural land with less than 0.5 buildings per hectare in 1936, decreasing to $49 \%$ in 1974 and $46 \%$ in 2018. This finding documents the intrinsic diversification of rural spaces toward intensive croplands and sparse settlements. By contrast, land with medium-high settlement density ( $>10$ buildings per hectare) - mostly representing fringe districts around Rome-comprised less than $2 \%$ of forest cover in 1936, and increased rapidly to $8 \%$ (1974) and $21 \%$ (2018).

According to the diverging socioeconomic contexts characterizing the study period, different urban-forest dynamics at the interface were delineated during the former (1936-1974) and the latter (1974-2018) time intervals. Although the fragmentation of forest cover was rather common in both periods, forest areas changed at different paces when considering both the total forest stock and selected wood types. An intense increase in forest cover was observed in marginal districts between 1936 and 1974. This was associated with a moderate decline in relict woodlands along the Tyrrhenian Sea coast. Between 1974 and 2018, forest cover was relatively stable in marginal districts, sometimes with a higher fragmentation level, although it expanded moderately along coastal areas and in flat districts close to Rome.

Settlement expansion, wildfires, and agricultural intensification during 1936-1974 were key factors shaping the physical structure of wildland-urban interfaces in Rome [8]. In particular, building density, the spatial configuration of settlements (mostly lowdensity and physically discontinuous), and the intrinsic characteristics of Mediterranean woodlands (e.g., low and intermediate vegetation cover, high sensitivity to wildfires, degraded/poor soils, and a dry climate preventing the rapid regeneration of burnt vegetation) influenced forest cover until the late 1970s [37]. Since the mid-1970s, however, forest cover showed a different evolution over time depending on the distance from downtown Rome. Forest land decreased far from the urbanized areas (corresponding to the low values of settlement density) over time, especially in the first period, and increased over time from a settlement density of $0.5-1$ building/ha to reach the highest extension in correspondence with settlement densities ranging from $2-5$ buildings/hectare to $10-50$ buildings/hectare. The three types of woods reveal the same trend, confirming a net expansion of the foresturban interface [48]. This trend suggests the increasing proximity of settlements and forests, likely in connection with urban expansion, the abandonment of some flat cropland and the consequent afforestation/reforestation over long time frames e.g., [49-51].

The empirical findings of our study give room for a thorough reflection of how the socio-environmental consequences of forest-urban dynamics in the metropolitan contexts of Southern Europe have contributed to sustainable/unsustainable landscape transformations. The simultaneous expansion of medium-low density settlements and scattered forest patches was assumed to increase the risk of wildfires [20]. The specific results of our study suggest how an important and counterintuitive assumption, i.e., forest expansion increases wildfire risk as much as peri-urban growth, should be investigated further using a comparative perspective. Starting from the long-term history of forest cover in Rome, such kinds of landscape dynamics require the following: (i) continuous monitoring in order to contain the risk of wildfire and (ii) spatial planning aimed at creating/maintaining natural or agricultural buffer areas between settlements and woods.

The results of our study also indicate the need for policy strategies that specifically address the urban-forest interactions within fringe landscapes [52]. As a matter of fact, wildland-urban interfaces are increasing rapidly in the Mediterranean basin along with dispersed urbanization e.g., [53], demographic change e.g., [54], and the abandonment of the agricultural areas surrounding the main cities e.g., [55]. With the disappearance of cropland from peri-urban landscapes often acting as a buffer between forest patches and 
urban settlements: [56], the proximity between buildings and woods tends to increase; this produces important changes in the composition, structure and diversity of landscapes at the wildland-urban interface e.g., [57]. The consequent increase in wildfire risk should be managed through forest plans addressing the specificity of peri-urban woods [58]. Fire risk, increased by the mixing of human structures/activities and fuels [59], may also affect forest biodiversity, which is in turn threatened by human disturbance, habitat loss, and pollutants due to their proximity to settlements $[19,47]$. These processes may determine a hardly reversible, downward environmental spiral $[60,61]$. Considering the established network of protected areas in Rome's metropolitan area and the focus of regional planning on agricultural policies [30,62], land management strategies should reinforce the intrinsic (ecological and economic) linkage between agricultural systems (declining over time) and an ever-expanding forest cover $[34,63,64]$. The abandonment of traditional cropland, forest biodiversity loss [65-67], and the mitigation of wildfire risk are related phenomena that should be addressed with appropriate measures in tune with the specificities of local contexts in metropolitan regions [68-70].

\section{Conclusions}

Landscape dynamics involving urban settlements and forest areas are anything but linear, and reflect a particularly complex evolution over time and space. Urban expansion creates a sort of 'resonance' effect on the surrounding landscape: although high-income farming systems try to oppose urbanization, the low-value, high-biodiversity agricultural mosaic tends to be more quickly developed. Such dynamics indirectly stimulate a progressive abandonment of marginal agricultural areas, which were re-colonized by natural forests in the long-term. The final result of these changes sees both urban areas and forest areas as possible 'predators' of the surrounding croplands, highlighting a sort of downward environmental spiral that leads to a simplification of complex peri-urban landscapes, which were originally based on the diversification of the agricultural matrix that was largely permeable to small rural settlements. How the persistence of such dynamics-consolidated in many European cities that also follow the application of environmental policies aimed at protecting natural areas and lack agricultural policies to support peri-urban farms-can lead to an excessively simplified and polarized landscape is a subject of intense research. The relationship between urban expansion, the simplification of fringe agro-forest mosaics, and biodiversity loss should be explicitly studied in landscape systems that are representative of contemporary European cities.

Author Contributions: Conceptualization, A.C. and L.B.; methodology, R.A.; software, A.S.; validation, V.D.S., A.C. and A.M.; formal analysis, A.S.; investigation, L.B.; resources, V.D.S.; data curation, A.C.; writing-original draft preparation, A.C.; writing—review and editing, A.S.; visualization, A.M.; supervision, A.C.; project administration, V.D.S.; funding acquisition, R.A. All authors have read and agreed to the published version of the manuscript.

Funding: This research received no external funding.

Institutional Review Board Statement: Not applicable.

Informed Consent Statement: Not applicable.

Data Availability Statement: Official statistics released by the Italian National Statistical Institute (Istat) were used in this study.

Conflicts of Interest: The authors declare no conflict of interest.

\section{References}

1. Marucci, A.; Colantoni, A.; Zambon, I.; Egidi, G. Precision farming in hilly areas: The use of network RTK in GNSS technology. Agriculture 2017, 7, 60. [CrossRef]

2. Vince, S.W. Forests at the Wildland-Urban Interface: Conservation and Management; Vince, S.W., Duryea, M.L., Macie, E.A., Hermansen, L.A., Eds.; CRC Press: Boca Raton, FL, USA, 2005; p. 293. 
3. Zambon, I.; Colantoni, A.; Carlucci, M.; Morrow, N.; Sateriano, A.; Salvati, L. Land quality, sustainable development and environmental degradation in agricultural districts: A computational approach based on entropy indexes. Environ. Impact Assess. Rev. 2017, 64, 37-46. [CrossRef]

4. Sala, O.E.; Chapin, F.S., 3rd; Armesto, J.J.; Berlow, E.; Bloomfield, J.; Dirzo, R.; Huber-Sanwald, E.; Huenneke, L.F.; Jackson, R.B.; Kinzig, A.; et al. Global biodiversity scenarios for the year 2100. Science 2000, 287. [CrossRef] [PubMed]

5. Sanderson, E.W.; Jaiteh, M.; Levy, M.A.; Redford, K.H.; Wannebo, A.V.; Woolmer, G. The Human Footprint and the Last of the Wild: The human footprint is a global map of human influence on the land surface, which suggests that human beings are stewards of nature, whether we like it or not. Bioscience 2002, 52, 891-904. [CrossRef]

6. Zipperer, W.C. Species composition and structure of regenerated and remnant forest patches within an urban landscape. Urban Ecosyst. 2002, 6, 271-290. [CrossRef]

7. Scarascia-Mugnozza, G.; Oswald, H.; Piussi, P.; Radoglou, K. Forests of the Mediterranean region: Gaps in knowledge and research needs. For. Ecol. Manag. 2000, 132, 97-109. [CrossRef]

8. Höchtl, F.; Lehringer, S.; Konold, W. "Wilderness": What it means when it becomes a reality-A case study from the southwestern Alps. Landsc. Urban Plan. 2005, 70, 85-95. [CrossRef]

9. Ciommi, M.; Chelli, F.M.; Carlucci, M.; Salvati, L. Urban Growth and Demographic Dynamics in Southern Europe: Toward a New Statistical Approach to Regional Science. Sustainability 2018, 10, 2765. [CrossRef]

10. Bajocco, S.; Dragoz, E.; Gitas, I.; Smiraglia, D.; Salvati, L.; Ricotta, C. Mapping Forest Fuels through Vegetation Phenology: The Role of Coarse-Resolution Satellite Time-Series. PLoS ONE 2015, 10, e0119811. [CrossRef] [PubMed]

11. Antrop, M. Landscape change and the urbanization process in Europe. Landsc. Urban Plan. 2004, 67, 9-26. [CrossRef]

12. Zambon, I.; Benedetti, A.; Ferrara, C.; Salvati, L. Soil Matters? A Multivariate Analysis of Socioeconomic Constraints to Urban Expansion in Mediterranean Europe. Ecol. Econ. 2018, 146, 173-183. [CrossRef]

13. Gambella, F.; Bianchini, L.; Cecchini, M.; Egidi, G.; Ferrara, A.; Salvati, L.; Colantoni, A.; Morea, D. Moving toward the north? The spatial shift of olive groves in Italy. Agric. Econ. 2021, 67, 129-135. [CrossRef]

14. Di Feliciantonio, C.; Salvati, L.; Sarantakou, E.; Rontos, K. Class diversification, economic growth and urban sprawl: Evidences from a pre-crisis European city. Qual. Quant. 2017, 52, 1501-1522. [CrossRef]

15. Nowak, D.J.; Walton, J.T.; Dwyer, J.F.; Kaya, L.G.; Myeong, S. The Increasing Influence of Urban Environments on US Forest Management. J. For. 2005, 103, 377-382.

16. Salvati, L. Towards a Polycentric Region? The Socio-economic Trajectory of Rome, an 'Eternally Mediterranean' City. Tijdschr. Econ. Soc. Geogr. 2014, 105, 268-284. [CrossRef]

17. Stewart, S.I.; Radeloff, V.C.; Hammer, R.B.; Hawbaker, T.J. Defining the Wildland-Urban Interface. J. For. 2007, 105, $201-207$.

18. Theobald, D.M.; Romme, W.H. Expansion of the US wildland-urban interface. Landsc. Urban Plan. 2007, 83, 340-354. [CrossRef]

19. Dwyer, J.F.; Chavez, D.J. The challenges of managing public lands in the wildland-urban interface. In Forests at the Wildlandurban Interface; Vince, S.W., Duryea, M.L., Macie, E.A., Hermansen, L.A., Eds.; CRC Press: Boca Raton, FL, USA, 2005 ; pp. 269-283.

20. Biasi, R.; Brunori, E.; Smiraglia, D.; Salvati, L. Linking traditional tree-crop landscapes and agro-biodiversity in central Italy using a database of typical and traditional products: A multiple risk assessment through a data mining analysis. Biodivers. Conserv. 2015, 24, 3009-3031. [CrossRef]

21. Chelleri, L.; Schuetze, T.; Salvati, L. Integrating resilience with urban sustainability in neglected neighborhoods: Challenges and opportunities of transitioning to decentralized water management in Mexico City. Habitat Int. 2015, 48, 122-130. [CrossRef]

22. Duvernoy, I.; Zambon, I.; Sateriano, A.; Salvati, L. Pictures from the other side of the fringe: Urban growth and peri-urban agriculture in a post-industrial city (Toulouse, France). J. Rural Stud. 2018, 57, 25-35. [CrossRef]

23. Perrin, C.; Nougarèdes, B.; Sini, L.; Branduini, P.; Salvati, L. Governance changes in peri-urban farmland protection following decentralisation: A comparison between Montpellier (France) and Rome (Italy). Land Use Policy 2018, 70, 535-546. [CrossRef]

24. Gambella, F.; Colantoni, A.; Egidi, G.; Morrow, N.; Prokopová, M.; Salvati, L.; Giménez-Morera, A.; Rodrigo-Comino, J. Uncovering the Role of Biophysical Factors and Socioeconomic Forces Shaping Soil Sensitivity to Degradation: Insights from Italy. Soil Syst. 2021, 5, 11. [CrossRef]

25. Champion, T. Urbanization, Suburbanization, Counterurbanization and Reurbanization. Handb. Urban Stud. 2001, 160, 143-161.

26. Carlucci, M.; Chelli, F.M.; Salvati, L. Toward a New Cycle: Short-Term Population Dynamics, Gentrification, and Re-Urbanization of Milan (Italy). Sustainability 2018, 10, 3014. [CrossRef]

27. Ciommi, M.; Chelli, F.M.; Salvati, L. Integrating parametric and non-parametric multivariate analysis of urban growth and commuting patterns in a European metropolitan area. Qual. Quant. 2019, 53, 957-979. [CrossRef]

28. Thompson, J.D. Plant Evolution in the Mediterranean. Plant Evol. Mediterr. 2007. [CrossRef]

29. Sirami, C.; Nespoulous, A.; Cheylan, J.P.; Marty, P.; Hvenegaard, G.T.; Geniez, P.; Schatz, B.; Martin, J.L. Long-term anthropogenic and ecological dynamics of a Mediterranean landscape: Impacts on multiple taxa. Landsc. Urban Plan. 2010, 96, $214-223$. [CrossRef]

30. Cecchini, M.; Zambon, I.; Pontrandolfi, A.; Turco, R.; Colantoni, A.; Mavrakis, A.; Salvati, L. Urban sprawl and the 'olive' landscape: Sustainable land management for 'crisis' cities. Geojournal 2018, 84, 237-255. [CrossRef]

31. Kosmas, C.; Karamesouti, M.; Kounalaki, K.; Detsis, V.; Vassiliou, P.; Salvati, L. Land degradation and long-term changes in agro-pastoral systems: An empirical analysis of ecological resilience in Asteroussia-Crete (Greece). Catena 2016, 147, 196-204. [CrossRef] 
32. Delfanti, L.; Colantoni, A.; Recanatesi, F.; Bencardino, M.; Sateriano, A.; Zambon, I.; Salvati, L. Solar plants, environmental degradation and local socioeconomic contexts: A case study in a Mediterranean country. Environ. Impact Assess. Rev. 2016, 61, 88-93. [CrossRef]

33. Recanatesi, F.; Clemente, M.; Grigoriadis, E.; Ranalli, F.; Zitti, M.; Salvati, L. A fifty-year sustainability assessment of Italian agro-forest districts. Sustainability 2016, 8, 32. [CrossRef]

34. Bielsa, I.; Pons, X.; Bunce, B. Agricultural abandonment in the North Eastern Iberian Peninsula: The use of basic landscape metrics to support planning. J. Environ. Plan. Manag. 2005, 48, 85-102. [CrossRef]

35. Busch, G. Future European agricultural landscapes-What can we learn from existing quantitative land use scenario studies? Agric. Ecosyst. Environ. 2006. [CrossRef]

36. Bajocco, S.; Ceccarelli, T.; Smiraglia, D.; Salvati, L.; Ricotta, C. Modeling the ecological niche of long-term land use changes: The role of biophysical factors. Ecol. Indic. 2016, 60, 231-236. [CrossRef]

37. Zambon, I.; Colantoni, A.; Salvati, L. Horizontal vs vertical growth: Understanding latent patterns of urban expansion in large metropolitan regions. Sci. Total Environ. 2019, 654, 778-785. [CrossRef]

38. Salvati, L.; Ciommi, M.T.; Serra, P.; Chelli, F.M. Exploring the spatial structure of housing prices under economic expansion and stagnation: The role of socio-demographic factors in metropolitan Rome, Italy. Land Use Policy 2019, 81, 143-152. [CrossRef]

39. Lamonica, G.R.; Recchioni, M.C.; Chelli, F.M.; Salvati, L. The efficiency of the cross-entropy method when estimating the technical coefficients of input-output tables. Spat. Econ. Anal. 2020, 15, 62-91. [CrossRef]

40. Bianchini, L.; Egidi, G.; Alhuseen, A.; Sateriano, A.; Cividino, S.; Clemente, M.; Imbrenda, V. Toward a Dualistic Growth? Population Increase and Land-Use Change in Rome, Italy. Land 2021, 10, 749. [CrossRef]

41. Cavallo, A.; Marino, D. Understanding changing in traditional agricultural landscapes: Towards a framework. J. Agric. Sci. Technol. 2012, 2, 971-987.

42. Attorre, F.; Bruno, M.; Francesconi, F.; Valenti, R.; Bruno, F. Landscape changes of Rome through tree-lined roads. Landsc. Urban Plan. 2000, 49, 115-128. [CrossRef]

43. Salvati, L.; Petitta, M.; Ceccarelli, T.; Perini, L.; Di Battista, F.; Scarascia, M.E.V. Italy's renewable water resources as estimated on the basis of the monthly water balance. Irrig. Drain. 2008, 57, 507-515. [CrossRef]

44. Ferrara, C.; Salvati, L.; Tombolini, I. An integrated evaluation of soil resource depletion from diachronic settlement maps and soil cartography in peri-urban Rome, Italy. Geoderma 2014, 232, 394-405. [CrossRef]

45. Konijnendijk, C.C. Enhancing the Forest Science-Policy Interface in Europe: Urban Forestry Showing the Way. Scand. J. For. Res. 2010, 19, 123-128. [CrossRef]

46. Badia-Perpinyà, A.; Pallares-Barbera, M. Spatial distribution of ignitions in Mediterranean periurban and rural areas: The case of Catalonia. Int. J. Wildl. Fire 2006, 15, 187-196. [CrossRef]

47. Badia, A.; Serra, P.; Modugno, S. Identifying dynamics of fire ignition probabilities in two representative Mediterranean wildland-urban interface areas. Appl. Geogr. 2011, 31, 930-940. [CrossRef]

48. Salvati, L.; Colantoni, A. Land use dynamics and soil quality in agro-forest systems: A country-scale assessment in Italy. J. Environ. Plan. Manag. 2015, 58, 175-188. [CrossRef]

49. Meireles, C.; Goncalves, P.; Rego, F.; Silveira, S. Estudo da regeneração natural das espécies arbóreas autóctones na Reserva Natural da Serra da Malcata. Silva. Lusit. 2005, 13, 217-231.

50. Spampinato, G.; Crisarà, R.; Cannavò, S.; Musarella, C.M. Phytotoponims of southern Calabria: A tool for the analysis of the landscape and its transformations. Atti Soc. Tosc. Sci. Nat. Mem. Ser. B 2017, 124, 61-72. [CrossRef]

51. Tonini, M.; Parente, J.; Pereira, M.G. Global assessment of rural-urban interface in Portugal related to land cover changes. Nat. Hazards Earth Syst. Sci. 2018, 18, 1647-1664. [CrossRef]

52. Su, S.; Wang, Y.; Luo, F.; Mai, G.; Pu, J. Peri-urban vegetated landscape pattern changes in relation to socioeconomic development. Ecol. Indic. 2014, 46, 477-486. [CrossRef]

53. Cuadrado-Ciuraneta, S.; Durà-Guimerà, A.; Salvati, L. Not only tourism: Unravelling suburbanization, second-home expansion and "rural" sprawl in Catalonia, Spain. Urban Geogr. 2017, 38, 66-89. [CrossRef]

54. Gavalas, V.S.; Rontos, K.; Salvati, L. Who becomes an unwed mother in Greece? Sociodemographic and geographical aspects of an emerging phenomenon. Popul. Space Place 2014, 20, 250-263. [CrossRef]

55. Modugno, S.; Balzter, H.; Cole, B.; Borrelli, P. Mapping regional patterns of large forest fires in Wildland-Urban Interface areas in Europe. J. Environ. Manag. 2016, 172, 112-126. [CrossRef] [PubMed]

56. Salvati, L.; Mavrakis, A.; Colantoni, A.; Mancino, G.; Ferrara, A. Complex adaptive systems, soil degradation and land sensitivity to desertification: A multivariate assessment of Italian agro-forest landscape. Sci. Total Environ. 2015, 521, 235-245. [CrossRef]

57. Serra, P.; Vera, A.; Tulla, A.F.; Salvati, L. Beyond urban-rural dichotomy: Exploring socioeconomic and land-use processes of change in Spain (1991-2011). Appl. Geogr. 2014, 55, 71-81. [CrossRef]

58. Fors, H.; Nielsen, A.B.; Konijnendijk Van Den Bosch, C.C.; Jansson, M. From borders to ecotones-Private-public co-management of urban woodland edges bordering private housing. Urban For. Urban Green. 2018, 30, 46-55. [CrossRef]

59. Whitman, E.; Rapaport, E.; Sherren, K. Modeling Fire Susceptibility to Delineate Wildland-Urban Interface for Municipal-Scale Fire Risk Management. Environ. Manag. 2013, 52, 1427-1439. [CrossRef] [PubMed]

60. Salvati, L.; Serra, P. Estimating rapidity of change in complex urban systems: A multidimensional, local-scale approach. Geogr. Anal. 2016, 48, 132-156. [CrossRef] 
61. Antrop, M. Changing patterns in the urbanized countryside of Western Europe. Landsc. Ecol. 2000, 15, 257-270. [CrossRef]

62. Arena, S.; Roda, I.; Chiacchio, F. Integrating Modelling of Maintenance Policies within a Stochastic Hybrid Automaton Framework of Dynamic Reliability. Appl. Sci. 2021, 11, 2300. [CrossRef]

63. Blondel, J.; Aronson, J.; Bodiou, J.Y.; Boeuf, G. The Mediterranean Region: Biological Diversity in Space and Time; Oxford University Press: Oxford, UK, 2010.

64. Falcucci, A.; Maiorano, L.; Boitani, L. Changes in land-use/land-cover patterns in Italy and their implications for biodiversity conservation. Landsc. Ecol. 2007, 22, 617-631. [CrossRef]

65. Salvati, L.; Zitti, M. Territorial disparities, natural resource distribution, and land degradation: A case study in southern Europe. GeoJournal 2007, 70, 185-194. [CrossRef]

66. Salvati, L.; Gemmiti, R.; Perini, L. Land degradation in Mediterranean urban areas: An unexplored link with planning? Area 2012, 44, 317-325. [CrossRef]

67. Plieninger, T.; Schaich, H.; Kizos, T. Land-use legacies in the forest structure of silvopastoral oak woodlands in the Eastern Mediterranean. Reg. Environ. Chang. 2011, 11, 603-615. [CrossRef]

68. Petit, C.C.; Lambin, E.F. Impact of data integration technique on historical land-use/land-cover change: Comparing historical maps with remote sensing data in the Belgian Ardennes. Landsc. Ecol. 2002, 17, 117-132. [CrossRef]

69. Orrù, P.F.; Zoccheddu, A.; Sassu, L.; Mattia, C.; Cozza, R.; Arena, S. Machine learning approach using MLP and SVM algorithms for the fault prediction of a centrifugal pump in the oil and gas industry. Sustainability 2020, 12, 4776. [CrossRef]

70. Luckenbill-Edds, L. The Educational Pipeline for Women in Biology: No Longer Leaking? Bioscience 2002, 52, 513-521. [CrossRef] 